\title{
PENERAPAN MODEL MATEMATIKA PENGUAPAN AIR KERIPIK SUKUN SELAMA DALAM PROSES PENGGORENGAN PADA TEKANAN HAMPA UDARA
}

\author{
Muhammad Akbar1), Kadirman2), dan Jamaluddin'3) \\ 1)Mahasiswa Program Studi Pendidikan Teknologi Pertanian FT UNM, \\ 2) dan ${ }^{3)}$ Dosen FT UNM \\ akbarptp011@gmail.com
}

\begin{abstract}
ABSTRAK
Penelitian ini bertujuan untuk mengetahui fenomena laju penguapan air keripik sukun pada penggorengan hampa udara dengan menerapkan model matematika. Keripik buah sukun digoreng pada tekanan $60 \mathrm{cmHg}, 65 \mathrm{cmHg}$ dan $70 \mathrm{cmHg}$ dengan lama penggorengan 15 menit, 30 menit, 45 menit dan 60 menit. Parameter pada penelitian ini adalah perubahan kadar air dan laju penguapan air. Pengolahan data menggunakan SPSS versi 20 dan perhitungan model matematika menggunakan Microsoft Excel. Hasil Penelitian menunjukkan bahwa tekanan hampa udara dan lama penggorengan berpengaruh terhadap perubahan kadar air dan laju penguapan air keripik sukun selama dalam proses penggorengan pada tekanan hampa udara. Semakin rendah tekanan hampa udara dan semakin lama waktu penggorengan maka semakin rendah kadar air keripik sukun yang dihasilkan.
\end{abstract}

Kata kunci : kadar air, laju penguapan air, tekanan hampa udara, lama penggorengan

\section{ABSTRACT}

This research was aimed to know the phenomenon of the water evaporation speed of breadfruits crackers in the vacuum frying process used the mathematic model apply. Breadfruits crackers were fried on the $60 \mathrm{cmHg}, 65 \mathrm{~cm} \mathrm{Hg}$, and $70 \mathrm{cmHg}$ with the duration of frying was 15 minutes, 30 minutes, 45 minutes, and 60 minutes. The parameter of this research was the change water content and water evaporation speed. Data processing was using SPSS version 2.0 and the mathematic model was using Microsoft Excel. The result of the research showed that the vacuum pressure and the duration of the frying process were influential toward the change in the water content and water evaporation speed of breadfruit crackers during frying process in the vacuum pressure. The less the vacuum pressure is the longer the frying process will be the less water content of breadfruit crackers produced.

\section{Keywords: water content, water evaporation speed, vacuum pressure and duration of frying process.}

\section{PENDAHULUAN}

Kekayaan alam yang melimpah di Indonesia patut untuk disyukuri. Alam tropis Indonesia memberikan anugerah yang cukup besar berupa keragaman hayati. Beragam flora tumbuh dan berkembang dengan baik diantaranya adalah buah-buahan yang merupakan komoditas pertanian yang banyak dibudidayakan di Indonesia. Buahbuahan banyak mengandung vitamin, 
mineral, dan serat yang bermanfaat bagi tubuh. Namun, buah-buahan sangat mudah rusak sehingga umur simpannya singkat. Bila tidak ditangani dengan baik, buah yang telah dipanen akan mengalami perubahan fisik, kimiawi dan biologis yang dapat menyebabkan buah rusak atau busuk. Misalnya buah sukun, sekalipun mengandung nutrisi yang cukup baik akan tetapi buah sukun mempunyai kelemahan yaitu mudah busuk dengan masa simpan 3 sampai 4 hari. Salah satu upaya mempertahankan mutu dan daya simpan buah adalah mengolahnya menjadi keripik sukun.

Sukun (Artocarpus altilis) termasuk dalam genus Artocarpus (famili moraceae) yang terdiri atas 50 spesies tanaman berkayu, yang hanya tumbuh di daerah panas dan lembab di kawasan Asia Tenggara dan kepulauan Pasifik. Buahnya berbentuk bulat berkulit tebal dan kasar, dengan warna hijau muda dan kuning dengan berat sekitar 1,5 - 3 $\mathrm{kg}$. Kandungan utama pada buah sukun selain kandungan air (65 - $85 \%)$ adalah karbohidrat $(21-32 \%)$, protein $(1,2-$ $2,4 \%)$, minyak $(0,2-0,5 \%)$, mineral, kalsium, phosfor, dan vitamin B1, B2, vitamin C dan vitamin A (Hakimah, 2010).

Hasil panen buah sukun selama ini hanya dikomsumsi sebagai gorengan sukun atau ditanak sebagai alternatif pengganti bahan pokok. Pemanfaatan seperti ini mempunyai beberapa kelemahan diantaranya pemasaran tidak menyebar luas, nilai jual rendah dan daya tahan gorengan sukun tidak lama, sehingga keuntungan juga rendah. Padahal buah sukun memiliki potensi besar untuk diolah, dimanfaatkan dan dikembangkan lebih lanjut menjadi produk-produk bernilai tambah ekonomi tinggi. Tidak saja sebagai sumber pangan pokok ataupun alternatif, atau gorengan sukun namun juga bisa diolah lebih lanjut menjadi keripik sukun.

Keripik sukun adalah produk makanan ringan, dibuat dari irisan daging buah sukun segar yang digoreng dengan atau tanpa bahan tambahan makanan yang diizinkan (SNI 01-42791996). Keripik sukun yang baik mempunyai kadar air rendah sehingga dapat disimpan lama. Salah satu cara untuk mendapatkan keripik sukun dengan kadar air rendah adalah dengan menggunakan vacuum frying.

Mesin penggorengan hampa udara (vacuum frying) dapat mengolah komoditas peka panas seperti buahbuahan menjadi hasil olahan berupa keripik (chips), seperti keripik sukun. Dibandingkan dengan penggorengan secara konvensional, sistem vakum menghasilkan produk yang jauh lebih baik dari segi penampakan warna, aroma, dan rasa karena relatif seperti buah. Pada kondisi vakum, suhu penggorengan dapat diturunkan menjadi 70-85 $\mathrm{C}$ karena penurunan titik didih minyak. Dengan demikian, kerusakan warna, aroma, rasa, dan nutrisi pada produk akibat panas dapat dihindari. Selain itu, kerusakan minyak dan akibat lain yang ditimbulkan karena suhu tinggi dapat diminimalkan karena proses dilakukan pada suhu dan tekanan rendah (Aeny, 2012).

Proses utama yang terjadi selama penggorengan adalah perpindahan panas dan massa, dengan minyak yang berfungsi sebagai media penghantar panas. Panas yang diterima bahan dipergunakan untuk penguapan air. Proses yang beragam ini harus dikendalikan sedemikian rupa sehingga tidak merusak mutu produk. Salah satu pengendaliannya adalah dengan 
mengatur waktu dan suhu penggorengan (Suprana, 2012).

Banyak penelitian telah dilakukan untuk menggambarkan kondisi dan perubahan yang terjadi selama proses penggorengan bahan pangan, namun belum banyak yang menerapkan model matematika penguapan air selama penggorengan pada tekanan hampa udara. Model matematika merupakan suatu persamaan yang diterapkan untuk memprediksi kadar air suatu bahan pangan selama proses pemanasan. Dengan demikian penelitian yang menjelaskan penerapan model matematika penguapan air keripik sukun selama dalam proses penggorengan pada tekanan hampa udara masih perlu dilakukan, agar kualitas produk keripik sukun yang dihasilkan dapat sesuai dengan standar mutu yang diinginkan utamanya yang berkaitan dengan kesehatan.

\section{METODE PENELITIAN}

Penelitian ini merupakan penelitian eksprimen yang terdiri atas 2 faktor. Faktor $A$ adalah tekanan dengan 3 taraf faktor $(60 \mathrm{cmHg}, 65 \mathrm{cmHg}$ dan 70 $\mathrm{cmHg}$ ) dan Faktor $\mathrm{B}$ adalah lama penggorengan dengan 4 taraf faktor 15 menit, 30 menit, 45 menit dan 60 menit). Dengan demikian banyaknya perlakuan yang dicobakan ada sebanyak 12 kombinasi perlakuan. Setiap kombinasi perlakuan diulang sebanyak 3 kali. Bahan baku utama yang digunakan adalah buah sukun yang diperoleh dari pasar Induk Sungguminasa. Bahan baku penunjang yang digunakan adalah minyak goreng, air, dan gas elpiji $3 \mathrm{~kg}$.

Alat- alat yang digunakan dalam penelitian ini adalah mesin penggoreng tekanan hampa kapasitas bahan $2 \mathrm{~kg}$, slicer, pisau, talenan, baskom, kompor gas merk Rinnai, timbangan digital, peniris minyak/spinner, spatula, panci, gelas ukur, oven, gell strengh, neraca analitik, stop watchl jam, gelas ukur, wadah plastik ukuran sedang.

Langkah persiapan meliputi persiapan sebelum penggorengan, yaitu buah sukun dikupas, dibersihkan, lalu diiris dengan ketebalan $4 \mathrm{~mm}$, kemudian buah sukun digoreng pada suhu $85^{\circ} \mathrm{C}$ dengan variasi perlakuan tekanan 60 $\mathrm{cmHg}, 65 \mathrm{cmHg}$, dan $70 \mathrm{cmHg}$ dan lama waktu penggorengan 15 menit, 30 menit, 45 menit, dan 60 menit. kemudian dimasukan ke dalam mesin spinner, dan dimasukan ke dalam desikator.

Data yang diperoleh dari penelitian ini berupa kadar air kripik pepaya, selanjutnya data tersebut dianalisis dengan menggunakan menggunakan program SPSS (Versi 20) dan perhitungan model matematika menggunakan Microsoft Excel 2013 untuk menghitung data laju penguapan air keripik sukun selama dalam proses penggorengan hampa udara.

Untuk mengetahui laju uap air bahan gorengan digunakan analogi Hukum Pendinginan Newton dengan analisis pengering yang dinyatakan dengan.

$\frac{M_{t}-M e}{M_{o}-M e}=-k_{c} \cdot t$

Keterangan:

Mt = kadar air bahan pada lama penggorengan t detik.

Mo = kadar air awal bahan .

$\mathrm{Me}=$ kadar air setimbang.

$-k_{c}=$ laju penguapan air.

$\mathrm{t}=$ lama penggorengan. 


\section{HASIL DAN PEMBAHASAN}

\section{Perubahan Kadar Air}

Pengamatan perubahan kadar air keripik sukun dilakukan sebelum dan setelah penggorengan. Kadar air diukur setiap 15 menit, untuk melihat perubahan kandungan air yang terjadi selama penggorengan berlangsung. Berdasarkan hasil pengujian analisis kadar air dapat dilihat pada Gambar 1.

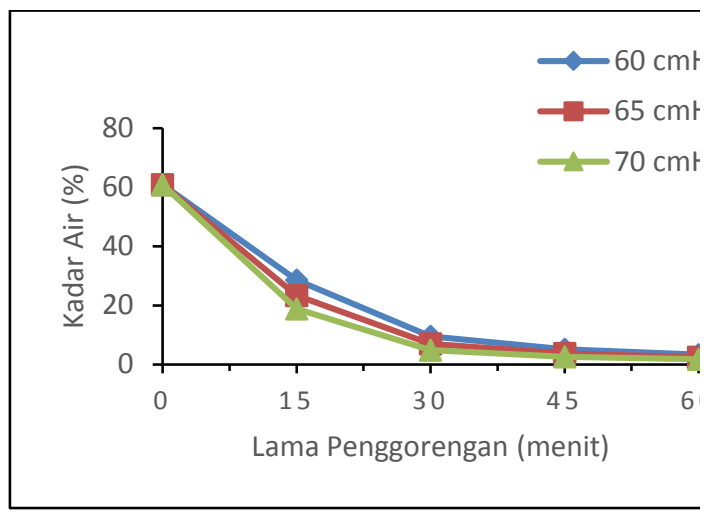

Gambar 1

Penurunan Kadar Air Keripik Sukun Selama dalam Proses Penggorengan pada Tekanan Hampa Udara

Dapat dilihat bahwa penurunan kadar air selama penggorengan bahan dipengaruhi oleh tekanan hampa udara dan lama waktu penggorengan. Semakin rendah tekanan hampa udara dan semakin lama waktu penggorengan maka kadar air keripik sukun semakin kecil. Hal ini disebabkan karena tekanan hampa udara yang semakin rendah menyebabkan penurunan titik didih minyak goreng, sehingga kadar air yang terkandung dalam bahan pangan lebih cepat menguap. Selain itu diketahui bahwa sebelum penggorengan, memperlihatkan kadar air yang sangat tinggi pada buah sukun. Pada waktu penggorengan 15 menit pertama, juga memperlihatkan kadar air yang masih tinggi. Terlihat bahwa penggorengan 15 menit pertama, kadar air akan turun secara perlahan. Hal tersebut dikarenakan pemanasan awal yang terjadi hanya menguapkan air bebas yang terdapat pada permukaan bahan saja. Air bebas merupakan air yang mudah menguap dari bahan makanan dikarenakan ikatan hidrogen yang lemah dalam air bebas (Winarno, 2002). Mailangkay (2002) juga menyatakan bahwa saat makanan diletakkan dalam minyak panas, suhu permukaan makanan dapat meningkat cepat menuju titik panas minyak sehingga air permukaan menguap, sedangkan suhu bagian dalam makanan meningkat secara perlahan.

Perubahan air yang cepat mulai terlihat pada menit 30 sampai menit ke 45. Hal tersebut dikarenakan pada tahap ini, kandungan air dipermukaan bahan telah menguap secara menyeluruh, sehingga penguapan air dilanjutkan ke bagian dalam bahan. Kandungan air yang cukup banyak terperangkap di dalam bahan, akan mengalami pemanasan lanjut kemudian menguap. Setelah penggorengan melewati menit ke 45, maka penurunan kadar air secara perlahan mulai konstan, penguapan air mulai berkurang, dan penguapan ini dapat diamati secara fisik, dengan berkurangnya gelembung udara pada minyak goreng. Hal ini dikarenakan kandungan air di dalam bahan sebagian besar telah menguap, sehingga hanya tersisa sedikit air di dalam padatan keripik sukun. Dengan demikian, penguapan kadar air pada tahap ini mengalami penurunan. Apabila perlakuan dilanjutkan pada penggorengan sampai 60 menit, kadar air keripik sukun akan cenderung konstan. 
Berdasarkan hasil pengamatan hubungan antara lama waktu penggorengan dengan penurunan kadar air dapat dilihat pada Gambar 2

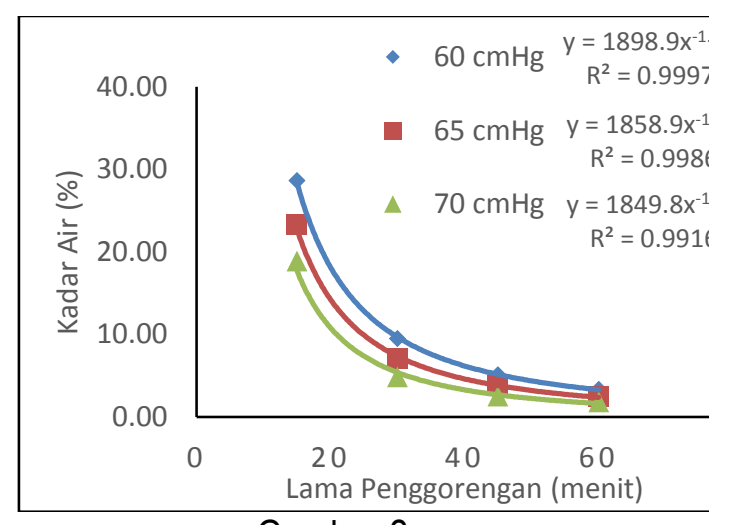

Gambar 2

Persamaan Garis Penurunan Kadar Air Keripik Sukun Selama dalam Proses Penggorengan pada Berbagai Perlakuan Tekanan Vakum

Berdasarkan Gambar 2 dapat dilihat bahwa penurunan kadar air selama penggorengan dipengaruhi oleh tekanan vakum dan waktu penggorengan. Semakin rendah tekanan vakum dan semakin lama waktu penggorengan maka kadar air keripik sukun semakin kecil. Penurunan kadar air keripik sukun disebabkan selama proses penggorengan titik didih air tidak mencapai $100^{\circ} \mathrm{C}$ sehingga air yang terkandung dalam bahan pangan lebih cepat menguap dan lama penguapan air dipengaruhi oleh tekanan hampa udara. Penelitian ini sesuai dengan pernyataan Jamaluddin, dkk (2011) yang menjelaskan bahwa buah yang digoreng pada suhu yang tinggi dan tekanan hampa udara yang semakin rendah ada kecenderungan penguapan air bebas semakin cepat atau sebaliknya. Penurunan kadar air keripik sukun mengikuti pola kecenderungan eksponensial dengan persamaan untuk tekanan $60 \mathrm{cmHg} y=1898,9 x^{-1,553}$ dengan
$\mathrm{R}^{2}=0,99$, tekanan $65 \mathrm{cmHg} y=1858,9-1,627$ dengan $\mathrm{R}^{2}=0,99$, dan pada tekanan 70 $\mathrm{cmHg} y=1849,8 \mathrm{x}^{-1,717}$ dengan $\mathrm{R}^{2}=0,99$. Menurut Edwards (1976) apabila nilai $\mathrm{R}^{2}$ lebih besar dari 0,75 model yang diuji dapat dinyatakan valid, dengan demikian model yang diterapkan dapat digunakan dengan baik untuk memprediksi penurunan kadar air selama proses penggorengan pada tekanan hampa udara.

\section{Laju Penguapan Air}

Hasil pengamatan hubungan antara lama waktu penggorengan dengan laju evaporasi dapat dilihat pada Gambar 3 berikut :



\section{Gambar 3}

Laju Penguapan Air Keripik Sukun

Selama dalam Proses Penggorengan pada Tekanan Hampa Udara

Berdasarkan hasil penelitian dapat diketahui bahwa laju penguapan air keripik sukun terendah ditunjukkan pada perlakuan tekanan $70 \mathrm{cmHg}$ dan disusul dengan perlakuan $65 \mathrm{cmHg}$ kemudian perlakuan $60 \mathrm{cmHg}$ untuk setiap lama waktu penggorengan yang sama. Selain itu dapat dilihat juga bahwa, laju penguapan air terendah diperlihatkan pada lama waktu pengggorengan 60 menit, disusul dengan lama waktu penggorengan 45 menit, kemudian lama waktu 
penggorengan 30 menit dan laju penguapan air tertinggi dengan lama waktu penggorengan 15 menit untuk setiap perlakuan tekanan yang sama.

Tingginya laju penguapan air pada waktu penggorengan 15 menit disebabkan karena banyaknya kandungan air pada bahan, sehingga penguapan air terlebih dahulu terjadi pada permukaan bahan. Selanjutnya penurunan laju penguapan air pada waktu penggorengan 30 menit mulai turun hal ini disebabkan karena sebagian besar air di permukaan bahan telah menguap sehingga penguapan air berlanjut ke bagian dalam bahan. Pada waktu penggorengan 45 menit sampai 60 menit laju penguapan air cenderung konstan, hal ini disebabkan laju penguapan air dari bahan telah menurun seiring dengan penurunan kadar air dalam bahan.

Laju penguapan air dipengaruhi oleh tekanan hampa udara, semakin rendah tekanan hampa udara maka semakin rendah laju penguapan air keripik sukun selama proses penggorengan. Selain itu, dapat dilihat bahwa laju penguapan air akan semakin menurun dengan semakin lamanya waktu penggorengan. Dimana laju penguapan air yang paling tinggi terdapat pada perlakuan waktu penggorengan 15 menit dan laju penguapan air paling rendah pada waktu 60 menit. Tingginya laju penguapan air pada waktu penggorengan 15 menit disebabkan karena banyaknya kandungan air pada bahan, sehingga penguapan air terlebih dahulu terjadi pada permukaan bahan. Air bebas merupakan air yang mudah menguap dari bahan makanan dikarenakan ikatan hidrogen yang lemah dalam air bebas (Winarno, 2002). Selanjutnya penurunan laju penguapan air pada waktu penggorengan 30 menit mulai turun hal ini disebabkan karena sebagian besar air di permukaan bahan telah menguap sehingga penguapan air berlanjut ke bagian dalam bahan. Pada waktu penggorengan 45 menit sampai 60 menit laju penguapan air cenderung konstan, hal ini disebabkan penguapan air dari bahan telah menurun seiring dengan penurunan kadar air selama proses penggorengan sehingga jumlah air bebas makin lama semakin berkurang dan permukaan partikel bahan tidak lagi ditutupi oleh lapisan air, sehingga laju penguapan air pada perlakuan ini mengalami penurunan dan cenderung konstan.

\section{Keterkaitan Perubahan Massa Air dan Laju Penguapan Air}

Hubungan antara perubahan massa air dengan laju penguapan air keripik sukun dapat dapat dilihat pada Gambar 4.

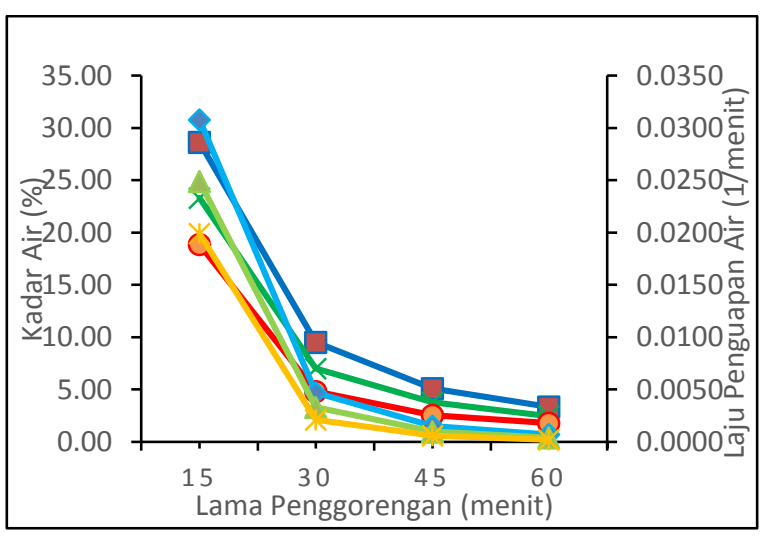

Gambar 4

Hubungan antara Perubahan Massa Air dan Laju Penguapan Air Keripik Sukun Selama dalam Proses Penggorengan pada Tekanan Hampa Udara.

Selama proses penggorengan terjadi fenomena penguapan air keripik sukun yang menyebabkan terjadinya perubahan kadar air pada bahan dan juga mempengaruhi laju penguapan air 
keripik sukun selama dalam proses penggorengan pada tekanan hampa udara.

Dapat dilihat bahwa perubahan kadar air keripik sukun berbanding lurus dengan perubahan laju penguapan air keripik sukun. Nampak bahwa semakin lama waktu penggorengan maka semakin rendah kadar air pada keripik sukun dan semakin turun laju penguapan air pada keripik sukun. Pada penggorengan 15 menit pertama kadar air dalam bahan masih tinggi dan laju penguapan air juga tinggi, hal ini disebabkan karena pada awal proses penggorengan air dalam bahan masih banyak dan proses penguapan air terjadi pada permukaan bahan sehingga laju penguapan air juga tinggi. Selanjutnya pada waktu penggorengan 30 menit kadar air mulai turun dan laju penguapan air juga semakin rendah, hal ini disebabkan berkurangnya air bebas pada bahan, sehingga proses penguapan air berlanjut ke bagian dalam bahan. Pada waktu penggorengan 45 menit dan 60 menit dapat dilihat bahwa perubahan kadar air mulai konstan dan laju penguapan air juga semakin rendah. Hal ini disebabkan air dalam bahan mulai berkurang sehingga laju penguapan air mulai menurun seiring dengan rendahnya kandungan air pada bahan.

\section{KESIMPULAN}

Berdasarkan hasil pembahasan diatas, maka dapat disimpulkan bahwa kadar air tertinggi pada penenelitian ini yaitu pada perlakuan $60 \mathrm{cmHg}$ dengan lama penggorengan 15 menit yaitu $28,6326 \%$ dan kadar air terendah yaitu pada perlakuan $70 \mathrm{cmHg}$ dengan lama penggorengan 60 menit yaitu $1,7989 \%$. Kadar air terbaik pada perlakuan tekanan $70 \mathrm{cmHg}$ dengan lama penggorengan 30 menit yaitu $4,8342 \%$. Semakin rendah tekanan hampa udara maka semakin rendah pula kadar air keripik sukun untuk perlakuan waktu yang sama. Model matematika laju penguapan air yang diterapkan dapat digunakan dengan baik untuk memperkirakan penurunan kadar air dan laju penguapan air keripik sukun selama dalam proses penggorengan pada tekanan hampa udara.

\section{DAFTAR PUSTAKA}

Aeny, Sri Nur. 2012. Analisa Pengaruh Perendaman Larutan $\mathrm{CaCl}_{2}$ Terhadap Sifat Organoleptik Keripik Terung Kopek Ungu (Solanum melongena L.) Dengan Sistem Penggorengan Hampa. Semarang. Program Diploma Fakultas Teknik Universitas Diponegoro.

Edwards, A. L. 1976. An Introduction to Linear Regretion on Correlation for India. National Seed Corporation. New Delhi.

Hakimah, I.A. 2010. Macam Buah Berkhasiat Istimewa. Bantul: Syura Media Utama.

Jamaluddin, Suardy, Siswantor, dan Suriana. 2011. Pengaruh Suhu dan Tekanan Vakum Terhadap Penguapan Air, Perubahan Volume dan Rasio Densitas Keripik Buah Selama dalam Proses Penggorengan Vakum. Jurnal Teknologi Peratanian Vol. 12 No. 2.

Mailangkay, Desy Natalia Irwanty, 2002. Pengaruh Kemasan Vakum dan Non Vakum Terhadap Perubahan Mutu Kimia dan Sifat Organoleptik Keripik Pisang Selama Penyimpanan. Institut Pertanian Bogor. 
Suprana, Yayang A. 2012. Pembuatan

Keripik Buah Menggunakan

Metode Penggorengan Vakum

dengan Variabel Suhu dan Waktu.

Tugas Akhir Fakultas Teknik,

UNDIP, Semarang.

Winarno, F.G., 2002. Kimia Pangan. 